UDC 378.147

DOI: https://doi.org/10.32820/2074-8922-2020-67-27-35

\title{
THE COMPETENCY-BASED APPROACH AS METHODOLOGY OF PROFESSIONAL TRAINING OF FUTURE TEACHERS IN THE CONDITIONS OF EDUCATION INFORMATIZATION
}

\author{
(C) Kharkivska A. A.
}

Municipal Establishment «Kharkiv Humanitarian Pedagogical Academy» of Kharkiv Regional Council

\section{Information about the Author}

Kharkivska Alla Anatoliivna: ORCID: 0000-0003-4782-1079; kharkivska_hgpa@ukr.net; Doctor of Pedagogical Sciences, Professor, Vice Rector on Scientific and Pedagogical Works; Municipal Establishment «Kharkiv Humanitarian Pedagogical Academy» of Kharkiv Regional Council; lane of Rustaveli , 7, City Kharkiv, 61001, Ukraine.

Economic, sociocultural and informational changes taking place in modern society, actualize the need to modernize the training system for future teachers. One of the main tasks of higher education should be quality training of a teacher, highly qualified, competent, competitive in the labor market, who will freely own their profession and navigate in related fields, ready for continuous professional development, selfeducation. By signing the Bologna declaration, Ukraine has legitimized the competence base of the state educational paradigm. The study is devoted to the issue of competency-based approach as methodology of professional training of future teachers in the conditions of education informatization. Based on the data of scientific achievements, the article analyzes and defines the essence of the concepts «competency-based approach», «competency», «competence». The main key competencies (including informative) that graduates of higher pedagogical education institutions should acquire are considered.

The author determined that the competency-based approach, in contrast to the traditional approach, involves not only acquiring knowledge, skills and abilities, but also forming and developing students' ability to adapt and act independently in standard and non-standard situations, quickly solve problems of varying complexity on the basis of acquired knowledge; competency means the level of education, ie mastering the necessary competences, and competence is considered a set of personality qualities that ensures the success of professional activities; information competence is interpreted as an integral quality of personality, the ability to use modern information and digital technologies in professional activities and the ability to model and design information and educational activities. The main principles of the competency-based approach are: orientation of the educational process on the formation and development of key and subject competencies of the individual; reorientation from the process to the result of education in the activitypersonality-oriented dimension; students' ability to solve problems that arise in different areas of activity.

Key words: competency-based approach, competency, competence, information competence, future teacher, informatization.

Харківська $\boldsymbol{A}$. $\boldsymbol{A}$. «Компетентнісний підхід як методологія професійної підготовки майбутніх учителів в умовах інформатизації освіти»

Економічні, соціокультурні, інформаційні зміни, що відбуваються в сучасному суспільстві, актуалізують необхідність модернізації системи підготовки майбутніх учителів. Одним із основних завдань вищої освіти повинно стати якісна підготовка педагогічного працівника, висококваліфікованого, компетентного, конкурентоздатного на ринку праці, який вільно володітиме своєю професією й орієнтуватися в суміжних сферах діяльності, готового до постійного професійного вдосконалення, самоосвіти. Україна, підписавши Болонську декларацію, узаконила компетентнісну основу державної освітньої парадигми. Дослідження присвячено питанню компетентнісного підходу як методології професійної підготовки майбутніх учителів в умовах інформатизації освіти. Базуючись на дані наукових доробок, у статті проаналізовано та визначено сутність понять «компетентнісний підхід», «компетентність», «компетенція». Розглянуто основні ключові компетентності (зокрема інформаційну), які повинні набути випускники закладів вищої педагогічної освіти. Автором визначено, що компетентнісний підхід, на відміну від традиційного підходу, передбачає не тільки набуття знань, умінь і навичок, а й формування і розвиток у здобувачів освіти здатності адаптуватися й самостійно діяти в стандартних і нестандартних ситуаціях, швидко вирішувати проблеми різної складності на основі набутих знань; компетентність позначає рівень освіченості, тобто оволодіння необхідних компетенцій, а компетенція розглядається як сукупність 
якостей особистості, що забезпечує успішність виконання професійної діяльності; інформаційну компетентність необхідно розглядати як інтегральну якість особистості, здатність самостійно використовувати сучасні інформаційні та цифрові технології в професійній діяльності та вміння моделювати i конструювати інформаційно-освітню діяльність. Основними принципами компетентнісного підходу є: орієнтація освітнього процесу на формування та розвиток ключових та предметних компетентностей особистості; переорієнтація від процесу на результат виховання в діяльнісно-особистісно-орієнтованому вимірі; здатність здобувачів освіти вирішувати проблеми, що виникають у різних сферах діяльності.

Ключові слова: компетентнісний підхід, компетентність, компетенція, інформаційна компетентність, майбутній учитель, інформатизація.

Харьковская $\boldsymbol{A} . \boldsymbol{A}$. «Компетентностный подход как методология профессиональной подготовки будущих учителей в условиях информатизации образования»

Экономические, социокультурные, информационные изменения, происходящие в современном обществе, актуализируют необходимость модернизации системы подготовки будущих учителей. Одной из основных задач высшего образования должно стать качественная подготовка педагога, высококвалифицированного, компетентного, конкурентоспособного на рынке труда, свободно владеющего своей профессией и который будет ориентироваться в смежных сферах деятельности, готового к постоянному профессиональному совершенствованию, самообразованию. Украина, подписав Болонскую декларацию, узаконила компетентностную основу государственной образовательной парадигмы. Исследование посвящено вопросу компетентностного подхода как методологии профессиональной подготовки будущих учителей в условиях информатизации образования. Основываясь на данные научных разработок, в статье проанализировано и определено сущность понятий «компетентностный подход», «компетентность», «компетенция». Рассмотрено основные ключевые компетентности (в частности информационную), которые должны приобрести выпускники учреждений высшего педагогического образования. Автором определено, что компетентностный подход, в отличие от традиционного подхода, предполагает не только приобретение знаний, умений и навыков, но и формирование и развитие у соискателей образования способности адаптироваться и самостоятельно действовать в стандартных и нестандартных ситуациях, быстро решать проблемы различной сложности на основе приобретенных знаний; компетентность обозначает уровень образованности, то есть овладение необходимыми компетенциями, а компетенция рассматривается как совокупность качеств личности, обеспечивающие успешность выполнения профессиональной деятельности; информационную компетентность необходимо рассматривать как интегральное качество личности, способность самостоятельно использовать современные информационные и цифровые технологии в профессиональной деятельности и умение моделировать и конструировать информационнообразовательную деятельность. Основными принципами компетентностного подхода являются: ориентация образовательного процесса на формирование и развитие ключевых и предметных компетентностей личности; переориентация от процесса на результат воспитания в деятельноличностно-ориентированном измерении; способность соискателей образования решать проблемы, возникающие в различных сферах деятельности.

Ключевые слова: компетентностный подход, компетентность, компетенция, информационная компетентность, будущий учитель, информатизация.

Problem statement. Reforming the education system in Ukraine involves the training of highly qualified, competitive, well-educated and creative teachers, endowed with a number of competencies, ready to use information, communication, digital technologies and teaching methods based on cooperation, responsible for each pedagogical action and act.

Introducing the concept of competencies in the normative and practical component of education allows to solve the issue when students can master theoretical knowledge but experience significant difficulties in activities that require applying the knowledge to solve specific issues or problem situations. Key competencies involve acquiring both knowledge and skills, mastering a complex procedure in which for each selected area there is a corresponding set of educational components that have a personal activity.

Developing key competencies of future teachers helps to increase their level of education necessary for successful life in general and 
professional activities in particular (selfconfidence, personal achievements, selfrealization, self-development, etc.).

Therefore, in the 21st century, the competency-based approach is a methodology that actively influences professional training of future teachers in the context of education informatization.

The competency-based approach is also key in the process of updating the content of higher education, which is aimed at developing the competencies of students based on the principles of fundamentality, versaility, integrity, flexibility, and practical orientation. Therefore, highlighting its main ideas in the context of improving professional training of future teachers in the context of education informatization is a currently relevant task.

Analysis of recent research works and publications. The issue of using the competencybased approach was researched by R. Barnett, N. Bibik, J. Bowden, O. Dubaseniuk, R. Guir, H. Havryshchak, R. Meyers O. Ovcharuk, O. Pometun, J. Raven, S. Savchenko, H. Shevchenko, S. Sysoeva, C. Velde, V. Verbytsky and others. The researchers emphasize that it is desirable to rely on the definition of «competence in education» when getting professional training of future teachers.

Researches on methodological fundamentals of forming and developing competencies of specialists in various areas are highlighted in the works of O. Denderenko (theoretical and methodological fundamentals of forming professional competencies of future ship mechanics); O. Hura (theoretical and methodological bases of forming psychological and pedagogical competence of a lecturer at a higher education establishment); V. Masych (competence approach as a methodological basis of formation of productive and creative competence of the future specialist); O. Turytsia (theoretical and methodological aspects of forming professional competence of future food production technologists) and others.

However, despite the works of researchers, the issue of using the competency-based approach as a methodology of professional training of future teachers in the context of education informatization has not been properly studied.

The purpose of the article is to analyze the main ideas of the competency-based approach as a methodology of professional training of future teachers in the conditions of education informatization.
Results and Discussion. Analysis of the genesis of the introduction of the competencybased approach in domestic and foreign higher education systems shows its application and restructuring of the higher education system over the past three decades. However, the preconditions for using a competency-based approach to education were formed earlier - in the middle of the twentieth century, when the development of the educational system of many countries ceased to correspond to the pace of development and renewal of knowledge. The discrepancy between the level of knowledge, skills and abilities acquired by a specialist during vocational education and the needs of the development of various spheres of production has become noticeable. After studying at a higher education institution, graduates were forced to retrain after entering production, as knowledge became obsolete during their studies, and industry, on the contrary, underwent constant modernization.

In today's conditions, certain changes have taken place in public life, which directly affected the educational process: education has become a mass phenomenon, industrial society has been replaced by information, the unambiguous estimates - their probability. Traditional education has faced the need to update its basic methodology. There was a need for another education - more flexible, which would focus not on the assimilation of information, but on the formation of qualities necessary for creative activity and self-assimilation of new knowledge. Therefore, the use of a competency-based approach to ensuring the successful training of future teachers is an urgent problem in the light of reforming the education system as a whole.

Thus, the competency-based approach in all aspects most deeply reflects the process of modernizing higher education both in all European countries and in Ukraine in particular. As O. Ovcharuk notes: «Current education should form in youth the ability to operate new technologies and knowledge, be ready to change and adapt to new needs of the labor market, operate and manage information, act in a dynamic way, make quick decisions, learn throughout life. As a European country, Ukraine cannot avoid all the above mentioned processes» $[9$, p. 6].

According to O. Pometun, the concept «the competency-based approach» should be understood as «the focus of the educational process on forming and developing key (basic, main), general and subject competencies of the personality» [11, p. 64]. 
V. Khymynets fully agrees with the above interpretation and notes that the main efforts of the traditional education system were focused on acquiring knowledge, skills and abilities, and this dogmatically absolutized knowledge and formed a cognitive approach to learning. The main focus was on knowledge itself but the reason itself is out of consideration. Thus, the competency-based approach shifts attention from the process of acquiring normatively defined knowledge, skills and abilities to form and develop students' ability to act and creatively apply the acquired knowledge and experience in various life situations [13].

N. Bibik argues that in education shifting to the competency-based approach «means reorienting from the process to the result of education in the activity dimension, ensuring abilities of graduates to meet new market demands, to have the potential to solve life problems, find their «I» in the profession» [1, p. 45].

N. Nahorna understands «the competencybased approach» as an ability of students to solve issues that arise in cognitive, technological and mental activities, in the areas of ethical, social, legal, professional and personal relationships [8].

T. Oliynyk believes that the competencybased approach is associated with personalityoriented and activity-based approaches to learning and requires transforming educational content, transiting from a model that exists objectively for all students to subjective achievements of one student, which can be determined [10, p. 69].

$\mathrm{X}$. Rogiers argues that, the competencybased approach relies on the following main objectives: emphasizing the competencies that the student must master at the end of each academic year and at the end of compulsory education, rather than stressing what the lecturer must teach. The role of the latter is to organize the learning outcomes in the best way so as to bring their students to the level expected [18, p. 106].

Summarizing the above-stated, one can make a conclusion that the competency-based approach, in contrast to the traditional approach, involves not only acquiring knowledge, skills and abilities, but also forming and developing students' ability to adapt and act independently in standard and non-standard situations, quickly solve problems of varying complexity on the basis of acquired knowledge.

According to $\mathrm{H}$. Shevchenko, the conceptual essence of the competency-based approach is: equipping students with a clearly defined system of professional competencies, which is objectified by the nature, level and trends of economy, science, education, culture - all areas and types of human life and society in our country and in Europe; in the educational process appealing to the person based on anthropological and axiological development principles (worldview, critical thinking, attitude to work, profession, to oneself and colleagues, selfesteem); using the specifics of personality-oriented approach as opposed to knowledge-oriented as a condition for modernizing higher education [14].

The main principles of the competencybased approach include: focusing the educational process on forming and developing key (basic, main) and subject competencies of the individual; reorienting from the process to the result of education in the activity and personality-oriented dimension; the ability of students to solve problems that arise in different areas of activity.

The main concepts of the competencybased approach are competency and competence.

In various sources, the concept of competency is interpreted as follows: «an important skill that is needed to do a job» [15]; a competent person is a person who has sufficient knowledge and is well versed in a particular field [2]

The Organization for Economic Cooperation and Development through Program for International Student Assessment has created a framework for comparing student competencies for purpose of assessment. The report showed that: "A competency is more than just knowledge and skills. It involves the ability to meet complex demands, by drawing on and mobilising psychosocial resources (including skills and attitudes) in a particular context ...» [19].
Ukrainian
researchers
O. Krysan,

O. Ovcharuk, O. Pometun, O. Lokshyna and O. Savchenko believe that competencies are a set of knowledge, skills and attitudes acquired when learning and allow a person to understand, ie identify and in different contexts evaluate issues that are specific to different areas of activity.

According to N. O'sullivan and A. Burce, competency consists of three interrelated ingredients: a knowledge component (the understanding part), behavioural components (the overt behavioural repertoire) and a value component (including values, beliefs and attitudes) [17].

According to S. Holovan, competency is «an integrative formation of personality that integrates knowledge, skills, abilities, experience and personal qualities that determine desire, ability and willingness to solve problems and tasks that arise in real life situations, at the same time realizing the importance of the subject and the result of the activity». He considers 
competence to be an alienated, predetermined requirement «to train a person (properties or qualities, potential abilities of a person)», a predetermined requirement «for knowledge and experience in a particular field» [3, p. 29].

M. Kalenyk states: «Competency is a personal characteristic of a set of internalized mobile knowledge, skills, abilities and flexible thinking». The researcher agrees with the opinion of S. Holovan about the essence of the concept of «competence» and emphasizes that «competencies are some alienated, pre-set requirements for educational training of graduates which are the «anatomy» of competency» [7, p. 117].

The analysis of the above stated interpretations gives grounds to conclude that competency means the level of education, ie mastering the necessary competences, and competence is considered a set of personality qualities that ensures the success of professional activities.

An approach to defining competences can be the following algorithm (fig. 1).

Thus, a competent specialist needs knowledge as a key entity that reflects the world unity and concentrates the reality of cognitive existence, development of generalized skills, abilities and personal experience in various fields of human activity, ability and willingness to apply them.

Consequently, considering professional training of future teachers in the context of education informatization, from the standpoint of the competency-based approach, leads to the conclusion that its result is the formation of key competencies for future professional activities (relevant knowledge, skills, values, other personal qualities) teaching.

The main features of key competencies include multifunctionality (competencies help to solve various problems in various spheres of personal and public life); supersubjectivity (competencies include knowledge, mental processes, intellectual, educational and practical skills, creative discoveries, strategies, technologies, procedures, emotions, assessments, etc.); ability to provide a wide range of personality development, its logical, creative and critical thinking, self-reflection, selfdetermination, self-esteem, self-education, etc.

The main key competences for lifelong learning are the European Parliament and the Council of the European Union: literacy; language competence; mathematical competence and science competence, technology and engineering; personal, social and educational competence; civic competence; entrepreneurial competence; competence of cultural awareness and selfexpression, as well as digital competence.

Forming key competencies occurs by acquiring a set of competences during training, which are a combination of characteristics (related to knowledge and their application, skills, abilities, values and personal qualities) and allow to ensure that professional responsibilities are carried out at a high level.

Key competencies are characterized by the fact that they allow to solve complex standard and non-standard tasks - various tasks of one kind (polyfunctionality), tasks in subject areas of human activity (interdisciplinarity and suprasubjectivity), which requires a high level of mental and cognitive abilities (multidimensionality) - intellectual competency.

For future teachers, pedagogical communication, emotional and volitional abilities which are a part of communicative and emotional competency are professionally significant. Mastering and applying skills of planning, forecasting, using adequate methods, means determine pedagogical competency.

When shifting to the information society, which is characterized by a constant increase in the amount of knowledge (information), the ability to navigate in information flows and to have information competency is more and more important for future teachers. Computer and digital technologies, which have become an integral part of modern society and have a significant impact on learning processes and education system as a whole, are used for effective information processing and professional problems.

The key basis that unites researches on forming and developing information competence is the concept of information.

In various sources, the concept of information (from the Latin informatio introduction, explanation, presentation, concept) is interpreted as follows: information about any events, someone's activities, etc.; a message about something; a set of information (data) that is perceived from the environment (input information), issued to the environment (output information) or stored in a certain system [6, p. 9]; it is all that reduces the degree of uncertainty about awareness of objects, phenomena, events [4, p. 16]; documented or publicly announced information about events and phenomena occurring in society, state and the environment [12].

The leading basis is an informationtechnical approach because any object of study, 


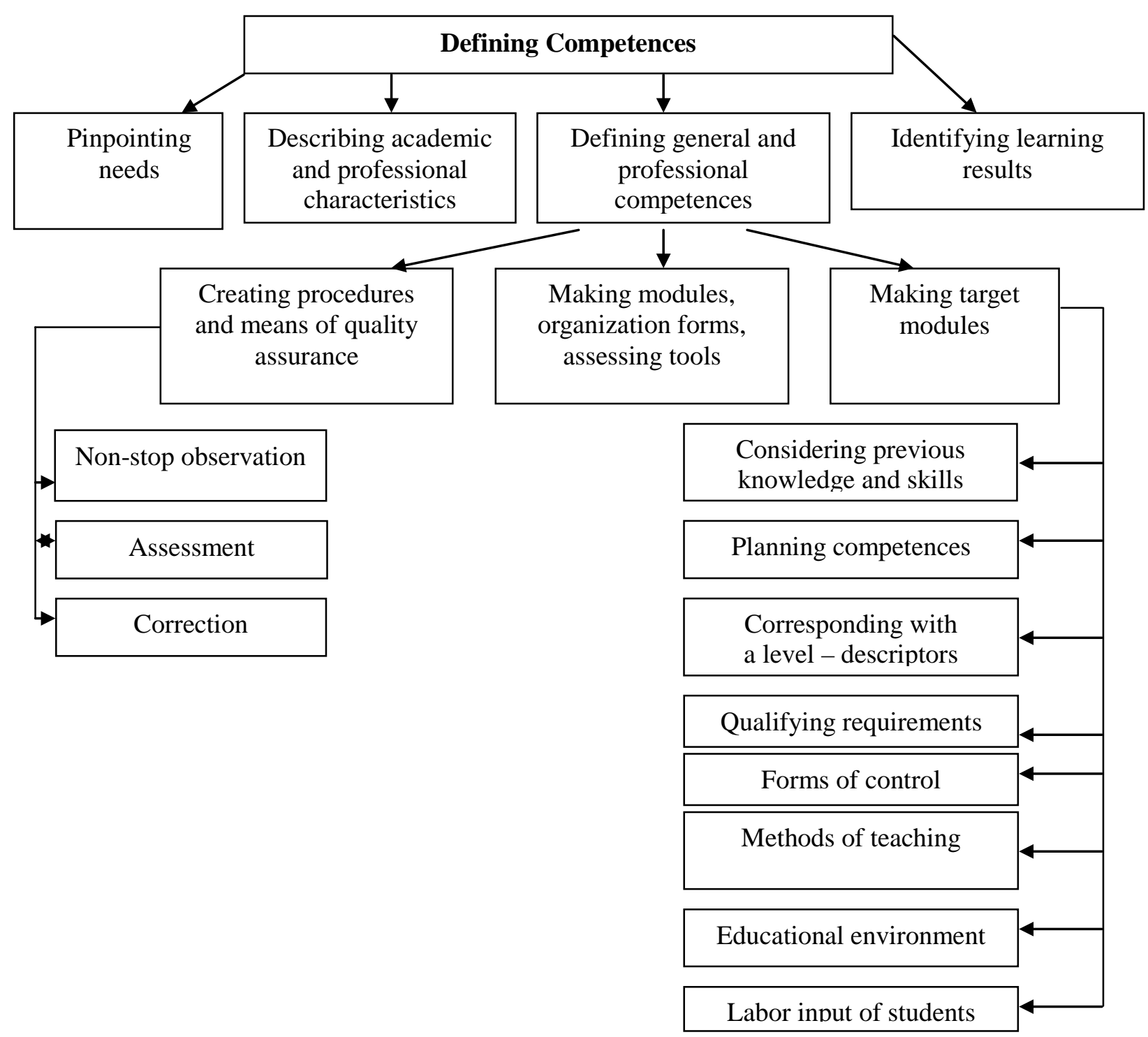

Figure 1. Algorithm for defining competences.

process, phenomenon, action has its isomorphic information reflection. Introduction of information, evolution of its values, nonlinear nature of complex processes of self-organization, occurring in complex systems in the material and intellectual spheres of human activity require a unified systematic approach to sciences, humanities and arts.

California Community Colleges Academic Senate believes that «information competency is the ability to find, evaluate, use, and communicate information in all its various formats. It combines aspects of library literacy, research methods, and technological literacy. Information competency includes consideration of the ethical and legal implications of information and requires the application of both critical thinking and communication skills» [16].

American Library Association, Association of College \& Research Libraries define information competency «as a set of abilities to recognize when information is needed and have the ability to locate, evaluate, and use effectively the needed information». This definition is further specified by a set of competency standards that emphasize five key skills. A person with a high level of information competence: «determines the nature and extent of the information needed; accesses needed information effectively and efficiently; evaluates information and its sources critically and incorporates selected information into his or her knowledge base and value system; individually or as a member of a group, uses information effectively to accomplish a specific purpose; understands many of the economic, legal, and social issues surrounding the use of information and accesses and uses information ethically and legally» [21].

L. Turusheva notes: «Information competence is a skill: to determine the size of the 
necessary information; to use the necessary information effectively; to evaluate the information and its sources critically; to develop own knowledge base with the information chosen; to effectively use the information for goal achievement; to use the information ethically» [20, p. 127].

We believe that information competence should be considered an integral quality of personality, an ability to independently use modern information and digital technologies in professional activities and an ability to model and design information-educational activities.

The properties of the category «information competence» are the following components: dualism - objective (external assessment of information competence) and subjective (internal - self-assessment of information competence) parties; relativity - knowledge quickly becomes outdated, they can be considered as new only in a conditionally defined spatio-temporal period; structuredness - each person has own, in a special way, organized knowledge base; selectivity - not all input information is transformed into knowledge that is embedded in existing organized knowledge bases; accumulative - knowledge and knowledge bases over time tend to accumulate accumulation, ie become wider, deeper, more voluminous; self-organization - the process of involuntary introduction in non-equilibrium systems of new knowledge base structures; multifunctionality - various subject-specific knowledge bases (a semantic component of knowledge bases is multifunctional) [5].

The functions of the categories «information competence» are: cognitive aimed at systematizing knowledge, cognition and self-knowledge; communicative, with a semantic component, «paper and electronic» media of pedagogical program complex; adaptive - allows you to adapt to living conditions and activities in the information society; normative, which is primarily a system of moral and legal norms and requirements in the information society; evaluative (informative), activates abilities to navigate in the flow of various information, to identify and select the well-known and the new, to evaluate the significant and the secondary; interactive - forms an active independent and creative work of the subject, leading to selfdevelopment and self-realization. These functions interact closely with each other, pass into each other and are in fact a single process [5].

Information competence can be manifested: in everyday life (as a result of information behavior and interaction, decision-making in everyday situations, and so on); educational process (in connection with the informatization of education); professional activities (in the process of educational practice of students, their participation in research work, and so on).

The formation of information competence of future teachers is carried out both directly in the classroom or in preparation for them (in the process of processing the results of educational experiments, when performing calculations and designing laboratory, term papers in academic disciplines, when searching for the necessary educational information), and during independent work, when students carry out any creative activity. For this, various automated teaching systems, mathematical calculation programs, computeraided design systems, application programs and so on can be used. Naturally, the more the higher education applicant uses the means of information, communication and digital technologies in educational, cognitive and professional activities, the higher the level of his information competence.

In our opinion, the informatization of the educational process is the most important condition for the formation of information competence of future teachers. Informatization of education involves the availability of any subject of the educational process to sources of information, the penetration of information and digital technologies in all areas of higher education.

Conclusion. Thus, modern professional training of future teachers in the context of informatization of education is impossible without taking into account the basic provisions of the competence approach. This approach involves the ability to create and make changes to the teacher's own professional activities, taking into account the needs and demands that will put before education the future society. competency-based approach - a new way to determine the results, the initial parameters of educational activities. The aim is to achieve not only a certain level of preparation of the graduate, but also his ability to work in modern conditions of dynamic change, both in the world of technology and in public life. The competency approach works with the concepts of «I can do», «I know how», answers the question of what a student should know, understand and be able to be highly qualified and competitive in the labor market. The formation of key competencies at different levels and levels of higher education is a necessary condition for the development of this area in the XXI century in the context of informatization of education and should take into account the competency model of the graduate. One of the competencies that should be 
formed and developed in future teachers is information competence, which is interpreted as an integral quality of personality, the ability to use modern information and digital technologies in professional activities and the ability to model and design information and educational activities.

\section{References}

1. Бібік Н. М. Компетентнісний підхід : рефлексивний аналіз застосування / Н. М. Бібік // Компетентнісний підхід у сучасній освіті: світовий досвід та українські перспективи : колективна монографія / під заг. ред. О. В. Овчарук. - Київ : K.I.C, 2004. - C. 45-50.

2. Великий тлумачний словник сучасної української мови (з дод. і допов.) / уклад. і голов. ред. В. Т. Бусел. - Київ ; Ірпінь : ВТФ «Перун», 2004. - 1440 c.

3. Головань М. С. Компетенція i компетентність: досвід теорії, теорія досвіду / М. С. Головань // Вища освіта України. - 2008. - № 3. - C. 23-30.

4. Згуровський М. 3. Вступ до комп’ютерних інформаційних технологій : навч. посібник / М. 3. Згуровський, I. І. Коваленко, В. М. Міхайленко. - Київ : Вид-во Європ. ун-ту, 2003. $-256 \mathrm{c}$.

5. Зелінський С. С. Формування інформатичної компетентності майбутніх інженерів у процесі професійної підготовки : дис. ... канд. пед. наук : 13.00.04 / Зелінський Сергій Сергійович ; ДВНЗ «Криворізький національний університет». Кривий Ріг, 2016. - 259 с.

6. Інформатика: Комп'ютерна техніка. Комп'ютерні технології : підручник для студентів вищих навчальних закладів / за заг. ред. О. І. Пушкаря. - Київ : Академія, 2002. - 704 с.

7. Каленик М. Поняття компетенція, компетентність, навчальні досягнення учнів 3 фізики / М. Каленик // Наукові записки Кіровоградського державного педагогічного університету імені Володимира Винниченка. Серія : Педагогічні науки. - 2010. - Вип. 90. - С. 117-120.

8. Нагорна Н. В. Формування у студентів понять компетентності й компетенції / Н. В. Нагорна // Виховання і культура. - 2007. - № 1-2 (11-12). - C. 266-268.

9. Овчарук О. В. Розвиток компетентнісного підходу: стратегічні орієнтири міжнародної спільноти / О. В. Овчарук // Компетентнісний підхід у сучасній освіті: світовий досвід та українські перспективи : колективна монографія / під заг. ред. О. В. Овчарук. Київ : К.І.С, 2004. - С. 5-14.

10. Олійник Т. С. Реалізація компетентнісного підходу в навчальному процесі на перекладацькому відділенні факультету іноземних мов ТНПу ім. В. Гнатюка / Т. С. Олійник // Професійні компетенції та компетентності вчителя : матеріали регіонального наук.-практ. семінару. - Тернопіль, 2006. - С. 69-71.
In the context of further solution of the problem it is relevant to consider improving the competence model of future teachers and developing a system for assessing the formation of information competence in graduates of higher education establishments.

11. Пометун О. I. Дискусія українських педагогів навколо питань запровадження компетентнісного підходу в українській освіті / O. I. Пометун // Компетентнісний підхід у сучасній освіті: світовий досвід та українські перспективи : колективна монографія / під заг. ред. О. В. Овчарук. - Київ : К.І.С, 2004. - С. 64-70.

12. Про інформацію : Закон України від 02.10.1992 р. № 2657-XII (зі змінами № 324-IX від 03.12.2019 р.) [Електронний ресурс]. - Режим доступу : https://zakon.rada.gov.ua/laws/show/265712\#Text. - Дата звернення 18.05.2020 p.

13. Химинець В. Компетентнісний підхід до професійного розвитку вчителя [Електронний pecypc]. - Режим доступу : http://zakinppo.org.ua/2010-01-18-13-44-15/233-201008-25-07-10-49. - Дата звернення 17.05.2020 p.

14. Шевченко Г. П. Концептуальна сутність компетентнісного підходу : європейський вимір / Г. П. Шевченко // Реалізація європейського досвіду компетентнісного підходу у вищій школі України : матеріали методологічного семінару. - Київ : Педагогічна думка, 2009. - С. 121-130.

15. Cambridge Dictionaries [Electronic resource]. - Access mode : https://cutt.ly/zy4pE2l. Viewed 18 May 2020.

16. Information Competency [Electronic resource]. - $\quad$ Access mode : http://www.orangecoastcollege.edu/academics/library/ Pages/Information-Competency.aspx. - Viewed 18 May 2020.

17. O'Sullivan N. Teaching and learning in competency-based education / N. O’Sullivan, A. Burce // The 5th Intern. Conf. on e-Learning (eLearning2014), 22-23 Sept. 2014, Belgrade, Serbia. - Belgrade, 2014. - Pp. 71-77.

18. Roegiers X. L’école et l'évaluation : Des situations pour évaluer les compétences des élèves / X. Roegiers. - France : Edition De Boeck, 2004. $367 \mathrm{p}$.

19. The definition and selection of key competencies [Electronic resource]. - Paris : OECD, 2005. - $19 \mathrm{p}$ - Access mode : https://www.oecd.org/pisa/35070367.pdf. - Viewed 19 May 2020.

20. Turusheva L. Students' information competence and its importance for life-long education / L. Turusheva // Problems of education in the 21st century. - 2009. - Vol. 12. - Pp. 126-132.

21. Vinta M. Information Competency [Electronic resource] / M. Vinta, M. A. Oviatt, M. S. Librarian. - Access mode : https://cutt.ly/zuOzYiz. Viewed 18 May 2020. 


\section{References}

1. Bibik, NM 2004, 'Kompetentnisnyi pidkhid : refleksyvnyi analiz zastosuvannia' [Competence approach: reflexive application analysis], in Ovcharuk, OV (ed.), Kompetentnisnyi pidkhid u suchasnii osviti: svitovyi dosvid ta ukrainski perspektyvy, K.I.S, Kyiv, pp. $45-50$.

2. Busel, VT 2004, Velykyi tlumachnyi slovnyk suchasnoi ukrainskoi movy [Great explanatory dictionary of modern Ukrainian language], VTF Perun, Kyiv, Irpin.

3. Holovan, MS 2008, 'Kompetentsiia i kompetentnist: dosvid teorii, teoriia dosvidu' [Competence and competency: experience of theory, theory of experience], Vyshcha osvita Ukrainy, no. 3, pp. 23-30.

4. Zghurovskyi, MZ, Kovalenko, II \& Mikhailenko, VM 2003, Vstup do kompiuternykh informatsiinykh tekhnolohii [Introduction to Computer Information Technology], Vydavnytstvo Yevropeiskoho universytetu, Kyiv.

5. Zelinskyi, SS 2016, 'Formuvannia informatychnoi kompetentnosti maibutnikh inzheneriv u protsesi profesiinoi pidhotovky' [The formation of informatics competence of future engineers during their professional training], Kand. ped. n. thesis, Kryvyi Rih.

6. Pushkar, OI 2002, Informatyka: Kompiuterna tekhnika. Kompiuterni tekhnolohii [Informatics: Computer technology. Computer technology], Vydavnychyi tsentr Akademiia, Kyiv.

7. Kalenyk, M 2010, 'Poniattia kompetentsiia, kompetentnist, navchalni dosiahnennia uchniv z fizyky’ [The concept of competence, competence, educational achievements of students in physics], Naukovi zapysky Kirovohradskoho derzhavnoho pedahohichnoho universytetu imeni Volodymyra Vynnychenka, Seriia Pedahohichni nauky, iss. 90, pp. 117-120.

8. Nahorna, NV 2007, 'Formuvannia u studentiv poniat kompetentnosti y kompetentsii' [Formation of students' concepts of competency and competence], Vykhovannia i kultura, no. 1-2 (11-12), pp. 266-268.

9. Ovcharuk, OV 2004, 'Rozvytok kompetentnisnoho pidkhodu: stratehichni oriientyry mizhnarodnoi spilnoty' [Development of a competency approach: strategic guidelines of the international community], in Ovcharuk, OV (ed.), Kompetentnisnyi pidkhid u suchasnii osviti: svitovyi dosvid ta ukrainski perspektyvy, K.I.S, Kyiv, pp. 5-14.

10. Oliinyk, TS 2006, 'Realizatsiia kompetentnisnoho pidkhodu $\mathrm{v}$ navchalnomu protsesi na perekladatskomu viddilenni fakultetu inozemnykh mov Ternopilskoho natsionalnoho pedahohichnoho universytetu imeni Volodymyra Hnatiuka' [Implementation of the competence approach in the educational process at the translation department of the Faculty of Foreign Languages of Ternopil Volodymyr Hnatiuk National Pedagogical University], Profesiini kompetentsii ta kompetentnosti vchytelia, Ternopil, pp. 69-71.

11. Pometun, OI 2004, 'Dyskusiia ukrainskykh pedahohiv navkolo pytan zaprovadzhennia kompetentnisnoho pidkhodu $\mathrm{V}$ ukrainskii osviti' [Discussion of Ukrainian teachers around the introduction of a competency-based approach in Ukrainian education], in Ovcharuk, OV (ed.), Kompetentnisnyi pidkhid u suchasnii osviti: svitovyi dosvid ta ukrainski perspektyv, K.I.S, Kyiv, pp. 64-70.

12. Prezydent Ukrainy 1992, Zakon Ukrainy Pro informatsiiu vid 02.10.1992 roku no. 2657-XII zi zminamy no. 324-IX vid 03.12.2019 roku [About information: Law of Ukraine, no. 2657-XII, 2 October, 1992], viewed 18 May 2020, <https://zakon.rada.gov.ua/laws/show/2657-12\#Text>.

13. Khymynets, V 2010, Kompetentnisnyi pidkhid do profesiinoho rozvytku vchytelia [Competence approach to teacher professional development], viewed 17 May 2020, $<$ http://zakinppo.org.ua/2010-01-18-13-44-15/2332010-08-25-07-10-49>.

14. Shevchenko, HP 2009, 'Kontseptualna sutnist kompetentnisnoho pidkhodu: yevropeiskyi vymir' [The conceptual essence of the competency approach: the European dimension], Realizatsiia yevropeiskoho dosvidu kompetentnisnoho pidkhodu u vyshchii shkoli Ukrainy, Pedahohichna dumka, Kyiv, pp .121-130

15. Cambridge Dictionaries n.d., viewed 18 May 2020, <https://cutt.ly/zy4pE2l>.

16. Information Competency n.d., viewed 18 May 2020, <http://www.orangecoastcollege.edu/academics/ library/Pages/Information-Competency.aspx>.

17. O’Sullivan, N \& Burce, A 2014, 'Teaching and learning in competency-based education', The 5th International Conference on e-Learning, Belgrade, pp. 71-77.

18. Roegiers, X 2004, L'école et l'évaluation : Des situations pour évaluer les compétences des élèves, Edition De Boeck, France.

19. The definition and selection of key competencies 2005, OECD, Paris, viewed 19 May 2020, <https://www.oecd.org/pisa/35070367.pdf>.

20. Turusheva, L 2009, 'Students' information competence and its importance for life-long education', Problems of education in the 21st century, vol. 12, pp. 126-132.

21. Vinta, M, Oviatt, MA \& Librarian, MS n.d., Information Competency, viewed 18 May 2020, $<$ https://cutt.ly/zuOzYiz $>$.

The article was edited 30 May 2020 